\title{
Factors associated with sarcopenia in subjects aged 80 years and over
}

\author{
Fatores associados à sarcopenia \\ em idosos longevos
}

Vanessa Ribeiro dos SANTOS ${ }^{1}$

Diego Giulliano Destro CHRISTOFARO ${ }^{1,2}$

Igor Conterato GOMES 3

Ricardo Ribeiro AGOSTINETE2

Ismael Forte FREITAS JÚNIOR ${ }^{1,2}$

Luís Alberto GOBBO2

\section{A B S T R A C T}

\section{Objective}

To analyze whether sarcopenia is associated with sociodemographic factors and chronic noncommunicable diseases in adults aged 80 years and older.

\section{Methods}

The sample consisted of 120 adults aged 80 to 95 years $(83.4 \pm 2.9$ years) from the city of Presidente Prudente (São Paulo, Brazil), of which 76 were females (83.4 \pm 3.0 years) and 44 were males $(83.4 \pm 2.6$ years). The study sociodemographic and epidemiological factors were: age stratum, gender, marital status, education level, chronic noncommunicable diseases, ethnicity, and nutritional status. Body composition was determined by Dual-Energy X-Ray Absorptiometry and sarcopenia was identified by the appendicular lean mass ratio (upper limb lean mass + lower limb lean mass $[\mathrm{kg}] /$ height $\left.[\mathrm{m}]^{2}\right)$. The Chi-square test analyzed whether sarcopenia was associated with sociodemographic and epidemiological factors and binary logistic regression expressed the magnitude of the associations. The data were treated by the software Statistical Package for the Social Sciences (17.0) at a significance level of $5 \%$.

\section{Results}

The factors associated with sarcopenia were gender, age, nutritional status, and osteopenia/osteoporosis.

${ }^{1}$ Universidade Estadual Paulista, Instituto de Biociências, Programa de Pós-Graduação em Ciências da Motricidade. Rio Claro, SP, Brasil.

2 Universidade Estadual Paulista, Faculdade de Ciências e Tecnologia de Presidente Prudente, Departamento de Educação Física. R. Roberto Simonsen, 305, Centro Educacional, 19060-900, Presidente Prudente, SP, Brasil. Correspondência paral Correspondence to: LA GOBBO. E-mail: <luisgobbo@fct.unesp.br>.

3 Universidade de São Paulo, Faculdade de Saúde Pública, Programa de Pós-Graduação em Saúde Pública. São Paulo, SP, Brasil. Article based on the master's thesis of VR SANTOS, intitled "Capacidade funcional, composição corporal e condições de saúde de idosos longevos". Universidade Estadual Paulista; 2012. 


\section{Conclusion}

The factors gender, age, nutritional status, and osteopenia/osteoporosis are independently associated with sarcopenia in adults aged 80 years and older.

Keywords: Chronic diseases. Aged, 80 and over. Demographic indicators. Sarcopenia.

\section{R E S U M O}

\section{Objetivo}

Analisar a associação entre sarcopenia, fatores sociodemográficos e doenças crônicas não transmissíveis em idosos longevos.

\section{Métodos}

A amostra foi constituída por 120 idosos - 76 mulheres (83,4 43,0 anos) e 44 homens (83,4 $\pm 2,6$ anos) -, com idade entre 80 e 95 anos (83,4 2, 9 anos), residentes na cidade de Presidente Prudente (SP), Brasil. Os fatores sociodemográficos e epidemiológicos investigados foram: estrato etário, sexo, estado civil, escolaridade, doenças crônicas não transmissíveis, etnia e estado nutricional. A análise da composição corporal foi feita pela técnica de absorptiometria de raios- $X$ de dupla energia, e, para identificação da sarcopenia, foi utilizada a razão da massa apendicular (massa magra dos membros superiores mais massa magra dos membros inferiores [kg]/ estatura $[\mathrm{m}]^{2}$ ). Para tratamento estatístico, foi empregado o teste Qui-quadrado para analisar a associação entre os fatores sociodemográficos, epidemiológicos e sarcopenia, e a análise de regressão logística binária foi utilizada para expressar a magnitude das associações. Foi utilizado o software Statistical Package for the Social Sciences (17.0), e o nivel de significância estabelecido foi de 5\%.

\section{Resultados}

Os fatores que se associaram com a sarcopenia foram: sexo, idade, estado nutricional, osteopenia/osteoporose.

\section{Conclusão}

O sexo, a idade, o estado nutricional e a presença de osteopenia/osteoporose são fatores que estão independentemente associados à sarcopenia em idosos longevos.

Palavras-chave: Doenças crônicas. Idosos 80 anos ou mais. Indicadores demográficos. Sarcopenia.

\section{INTRODUCTION}

The reduction in strength and Muscle Mass (MM) that accompanies ageing is defined as sarcopenia ${ }^{1}$, which in turn is very prevalent in older adults of all ages, especially the very old ones².

Sarcopenia is one of the most widely used variables for indicating reduced mobility and functional capacity and increased frailty in older adults, increasing the risk of falls and fractures, dependence on others to carry out activities of daily living, hospitalizations, and early death ${ }^{3,4}$.

The development of sarcopenia seems to stem from a numerical reduction in motor neurons, muscle fiber atrophy, especially of the type IIA, a decrease in anabolic hormones, an increase in pro-inflammatory cytokines, and changes in protein and calorie intakes that occur with ageing ${ }^{1,5,6}$.
Studies have cited some factors that may be associated with sarcopenia, namely gender ${ }^{2,7}$, Chronic Noncommunicable Diseases (NCD), especially osteoarticular diseases ${ }^{8,9}$, and nutritional status $^{10}$. The identification of such factors is important to prevent frailty and functional incapacity in older adults of all ages, especially the very old ones. However, there is a lack of studies that investigate such aspects in adults aged 80 years and older. Hence, the objective of this study was to analyze whether sarcopenia is associated with sociodemographic factors and NCD in very old adults.

\section{METHODS}

This cross-sectional study was conducted between October 2009 and May 2010 in the city 
of Presidente Prudente (approximately 210,000 inhabitants), located in the western region of the state of São Paulo, Brazil11.

The participants were chosen by convenience sampling. A total of 135 female and male adults aged 80 years and older from the abovementioned city were invited to participate in the study. The municipal Department of Health provided the name, address, and telephone number of users of the municipal health care system. The study was advertised in the local media, and the individuals were invited to join by telephone. The inclusion criteria were: age 80 years and older and having lived in Presidente Prudente (SP) for at least two years. The exclusion criteria were: inability to walk, being bedridden, living in rural areas, using pacemakers, and incomplete personal data in the database. The final sample consisted of 120 individuals.

The participants were informed about the study objectives and data collection methodology, and that they were free to drop out of the study at any time. Only those who signed an informed consent form were allowed to join the study. All protocols were reviewed and approved by the Research Ethics Committee of Universidade Estadual Paulista (Process n 26/2009).

\section{Sociodemographic factors and chronic noncommunicable diseases}

Age stratum (80-84 years and $\geq 85$ years), gender, marital status, education level, ethnicity, and study NCD (high blood pressure, diabetes, and osteopenia/osteoporosis) were collected by a short version of the questionnaire Saúde, Bem-Estar e Envelhecimento (SABE, Health, Wellbeing, and Ageing), which covers many aspects of the lives of older adults, such as personal information, cognitive assessment, health status, functional status, work history, income source, mobility, and anthropometry ${ }^{12}$.

\section{Nutritional status}

Body Mass Index (BMI) was used for classifying nutritional status.
Body weight was measured by the electronic scale Filizola ${ }^{\circledR}$, with maximum capacity of $180 \mathrm{~kg}$ and accuracy of $0.1 \mathrm{~kg}$. Height was measured by the fixed stadiometer Sanny ${ }^{\circledR}$, with a length of $2.20 \mathrm{~m}$ and accuracy of $0.1 \mathrm{~cm}$. These measurements were used for calculating $\mathrm{BMI}$ [weight $(\mathrm{kg}) /$ height $\left.(\mathrm{m})^{2}\right]$. The nutritional status cut-off points were: underweight $<23 \mathrm{~kg} / \mathrm{m}^{2}$; $23 \mathrm{~kg} / \mathrm{m}^{2} \leq$ normal weight $<28 \mathrm{~kg} / \mathrm{m}^{2}$; and obese $\geq 28 \mathrm{~kg} / \mathrm{m}^{2}$ as suggested by Troiano et al. ${ }^{13}$

\section{Dual-Energy X-Ray Absorptiometry}

Body composition was determined by the Dual-Energy X-Ray Absorptiometry (DXA) device Lunar, model DPX-MD, software 4.7, using the three-compartment model (lean body mass, fat mass, and mineral mass). This technique estimates the total and compartmental body composition.

\section{Osteopenia/Osteoporosis}

Osteopenia and osteoporosis diagnoses were based on the bone mineral density of the proximal femur provided by the DXA device. The examination followed the manufacturer's recommendations and the diagnoses were based on the criteria established by the World Health Organization $(\mathrm{WHO})^{14}$.

\section{Sarcopenia}

Sarcopenia was classified according to the Appendicular Muscle Mass Index (AMMI in $\mathrm{kg} / \mathrm{m}^{2}$ ), given by the ratio appendicular muscle mass (upper limb muscle mass + lower limb muscle mass, in kilograms) to height (in square meters). Men with AMMI $<7.59 \mathrm{~kg} / \mathrm{m}^{2}$ and women with $\mathrm{AMMl}<5.57 \mathrm{~kg} / \mathrm{m}^{2}$ were considered sarcopenic. These cut-off points were based on two standard deviations below the mean of a young group [ $\mathrm{n}=60$ ( 25 men and 35 women) aged 20 to 30 years, as suggested by Baumgartner et al. ${ }^{2}$. 


\section{Statistical analysis}

The Chi-square test analyzed whether sarcopenia was associated with the study sociodemographic factors and chronic noncommunicable diseases. Univariate binary logistic regression expressed the magnitude of the associations in Odds Ratios (OR) and respective 95\% Confidence Intervals $(95 \% \mathrm{CI})$. All variables with $p<0.20$ in the Chi-square test were included in the multiple binary logistic regression model using the forward stepwise modeling strategy. The data were treated by the software Statistical Package for the Social Sciences (SPSS) version 17.0 at a significance level of $5 \%$.

\section{RES U LT S}

The present sample consisted of 120 adults aged 80 to 95 years $(83.4 \pm 2.9$ years), of which
76 were females ( $83.4 \pm 3$ years) and 44 were males (83.4 \pm 2.6 years).

Table 1 shows the association between sarcopenia and sociodemographic factors. A greater proportion of older adults with sarcopenia were underweight $(p=0.003)$ males $(p=0.002)$ aged 80 to 84 years $(p=0.011)$.

Table 2 shows the association between sarcopenia and NDC. A greater proportion of older adults with sarcopenia had osteopenia/ osteoporosis ( $p=0.002$ ).

Table 3 shows the magnitude of the associations expressed as the odds ratio of sarcopenia for sociodemographic factors and chronic noncommunicable diseases. Males, males aged more than 85 years, underweight males, and males with osteopenia/osteoporosis are 3.68 $(p=0.002), 3.17(p=0.013), 3.34(p=0.003), 4.33$ $(p=0.003)$ times more likely to have sarcopenia, respectively.

Table 1. Association between sarcopenia and sociodemographic factors.

\begin{tabular}{|c|c|c|c|c|}
\hline \multirow{2}{*}{ Variables } & \multirow{2}{*}{ Total (n) } & \multicolumn{2}{|c|}{ Sarcopenia \% } & \multirow{2}{*}{$p$} \\
\hline & & No (88) & Yes (32) & \\
\hline \multicolumn{5}{|l|}{ Gender } \\
\hline Male & 44 & 20.8 & 15.8 & \multirow{2}{*}{0.002} \\
\hline Female & 76 & 52.5 & 10.8 & \\
\hline \multicolumn{5}{|l|}{ Age } \\
\hline $80-84$ & 94 & 61.7 & 16.7 & \multirow{2}{*}{0.011} \\
\hline$\geq 85$ & 26 & 11.7 & 10.0 & \\
\hline \multicolumn{5}{|l|}{ Nutritional status } \\
\hline Underweight & 33 & 14.2 & 13.3 & \multirow{3}{*}{0.003} \\
\hline Normal weight & 50 & 32.5 & 9.2 & \\
\hline Obese & 37 & 26.7 & 4.2 & \\
\hline \multicolumn{5}{|l|}{ Education Level } \\
\hline No education & 36 & 18.3 & 11.7 & \multirow{3}{*}{0.298} \\
\hline Elementary school & 70 & 47.5 & 10.8 & \\
\hline High school/higher education & 14 & 7.5 & 4.2 & \\
\hline \multicolumn{5}{|l|}{ Marital status } \\
\hline Single/separated & 9 & 5.0 & 2.5 & \multirow{3}{*}{0.675} \\
\hline Married/has partner & 46 & 29.2 & 9.2 & \\
\hline Widowed & 65 & 39.2 & 15.0 & \\
\hline \multicolumn{5}{|l|}{ Ethnicity } \\
\hline White & 70 & 45.0 & 13.3 & \multirow{4}{*}{0.659} \\
\hline Black & 6 & 2.5 & 2.5 & \\
\hline Asian & 17 & 8.3 & 5.8 & \\
\hline Brown & 27 & 17.5 & 5.0 & \\
\hline
\end{tabular}


Table 2. Association between sarcopenia and chronic noncommunicable diseases.

\begin{tabular}{|c|c|c|c|c|}
\hline \multirow{2}{*}{ Diseases } & \multirow{2}{*}{ Total (n) } & \multicolumn{2}{|c|}{ Sarcopenia \% } & \multirow{2}{*}{$p$} \\
\hline & & No (88) & Yes (32) & \\
\hline \multicolumn{5}{|c|}{ Hypertension } \\
\hline yes & 77 & 48.3 & 14,2 & \multirow{2}{*}{0.129} \\
\hline no & 43 & 22.5 & 12.5 & \\
\hline \multicolumn{5}{|l|}{ Diabetes } \\
\hline yes & 23 & 15.0 & 3.3 & \multirow{2}{*}{0.284} \\
\hline no & 97 & 55.8 & 23.3 & \\
\hline \multicolumn{5}{|c|}{ Osteopenia/Osteoporosis } \\
\hline yes & 70 & 36.7 & 21.7 & \multirow{2}{*}{0.002} \\
\hline no & 50 & 36.7 & 5.0 & \\
\hline
\end{tabular}

Table 3. Odds Ratios (OR) for sarcopenia according to sociodemographic factors and chronic noncommunicable diseases.

\begin{tabular}{lccc}
\hline Variables & OR & C195\% & $p$ \\
\hline Gender & 1.00 & - & 0.002 \\
Female & 3.68 & $1.58-8.56$ & \\
Male & & & 0.013 \\
Age & 1.00 & $1.27-7.92$ & \\
$80-84$ years & 3.17 & & 0.013 \\
$\geq 85$ years & & - & 0.317 \\
Nutritional status & 1.00 & $1.28-8.68$ & \\
Normal weight & 3.34 & $0.17-1.76$ & \\
Underweight & 0.55 & & 0.132 \\
Obese & & - & \\
High blood pressure & 1.00 & $0.23-1.21$ & \\
No & 0.53 & & 0.003 \\
Yes & & $1.62-11.56$ & \\
Osteopenia/osteoporosis & 1.00 & & \\
No & 4.33 & & \\
Yes & & & \\
\hline
\end{tabular}

Note: C195\%: 95\% Confidence Interval.

Table 4. Multiple regression model with sociodemographic factors associated with sarcopenia in adults aged 80 years and older.

\begin{tabular}{|c|c|c|c|}
\hline Variables & $A O R$ & $95 \% \mathrm{Cl}$ & $p$ \\
\hline \multicolumn{4}{|l|}{ Gender } \\
\hline Male & 4.32 & $1.66-11.23$ & 0.003 \\
\hline \multicolumn{4}{|l|}{ Nutritional status } \\
\hline Underweight & 5.14 & $1.94-13.57$ & 0.001 \\
\hline \multicolumn{4}{|l|}{ Age } \\
\hline 80-84 years & 1.00 & - & \\
\hline$\geq 85$ years & 3.60 & $1.30-9.97$ & 0.014 \\
\hline
\end{tabular}

Note: Hosmer and Lemeshow test=0.48; AOR: Adjusted Odds Ratio.

C195\%: 95\% Confidence Interval. 
Table 5. Multiple regression model with the chronic noncommunicable diseases associated with sarcopenia in adults aged 80 years and older.

\begin{tabular}{lccc}
\hline Variables & AOR & $95 \% \mathrm{Cl}$ & $p$ \\
\hline Osteopenia/osteoporosis & & & \\
No & 1.00 & - & 0.035 \\
Yes & 2.82 & $1.07-7.38$ & \\
High blood pressure & & & \\
No & 1.00 & - & 0.315 \\
Yes & 0.64 & $0.27-1.53$ & \\
Age & & & 0.075 \\
$80-84$ years & 1.00 & $0.92-6.19$ & \\
$\geq 85$ years & 2.38 & &
\end{tabular}

Note: Hosmer and Lemeshow test=0.99; AOR: Adjusted Odds Ratio, model adjusted for age. C195\%: 95\% Confidence Interval.

Table 4 shows the multiple model containing the sociodemographic variables associated with sarcopenia. The sociodemographic factors gender, nutritional status, and age are independently associated with sarcopenia.

Table 5 shows the multiple model of the NCD associated with sarcopenia adjusted for age. Older adults with osteopenia/osteoporosis are $2.82(p=0.035)$ times more likely to have sarcopenia regardless of age and having high blood pressure.

\section{DISCUSSION}

The present study aimed to analyze which sociodemographic factors and chronic noncommunicable diseases are associated with sarcopenia in very old adults. Osteopenia/osteoporosis, age, gender, and nutritional status were found to be associated with sarcopenia in this group.

Age and gender are factors that can be associated with sarcopenia. Men have higher MM and higher incidence of sarcopenia than women ${ }^{15}$. Greater ageing-related MM loss in men stems from a decrease in growth hormone and testosterone ${ }^{16}$. This datum was found by Janssen et al. ${ }^{7}$, who reported a prevalence of sarcopenia in older adults of $31 \%$ for women and $64 \%$ for men. In New Mexico Baumgartner et al. ${ }^{2}$ found that the prevalence of sarcopenia was greater in very old adults, especially males. Our results corroborate these findings since the likelihood of this age group presenting sarcopenia is approximately three times greater than that of older adults aged 80 to 84 years, and males are approximately four times more likely to have sarcopenia than females.

Using Appendicular Muscle Man Index, Newman et al. ${ }^{17}$ found prevalences of sarcopenia in overweight and obese men of $8.9 \%$ and $0.0 \%$, respectively; and in overweight and obese women, of $7.1 \%$ and $0.0 \%$, respectively. Some years later Lee et al. ${ }^{10}$ found that sarcopenia is associated with underweight and consequently, with physical limitations in older Chinese males and females. Our finding corroborates Lee et al. ${ }^{10}$, who also found an association between sarcopenia and underweight in very old adults, who in turn were three times more likely to have the disease. Low protein intake by underweight adults may explain this association since low protein intake reduces muscle mass ${ }^{18}$.

The present study investigated the association between sarcopenia and education level since individuals with higher education level also have higher purchasing power, allowing them to purchase more high-protein foods, enabling them to maintain muscle mass ${ }^{19,20}$. However, no 
association was found between sarcopenia and education level in very old adults.

The prevalences of sarcopenia found in American male and female whites were $25.2 \%$ and $31.4 \%$, respectively, and in blacks, $11.8 \%$ and $6.8 \%$, respectively ${ }^{21}$. Lau et al. ${ }^{22}$ found prevalences of $12.3 \%$ and $7.2 \%$ in Chinese males and females aged more than 70 years, respectively. The smaller prevalence of sarcopenia found in blacks may stem from their different amount of lean body mass since blacks have more skeletal muscle at any age than whites ${ }^{23}$. Therefore, there may be ethnic differences in agerelated muscle loss. However, the present study did not find an association between sarcopenia and ethnicity.

Skeletal muscle is the main glucose consumer directly associated with insulin activity. Thus, the metabolic effects of sarcopenia include lower resting energy expenditure and fat oxidation, increasing the prevalences of insulin resistance, diabetes mellitus, dyslipidemia, and high blood pressure ${ }^{24}$. Nevertheless, Lee et al. ${ }^{10}$ did not find sarcopenia to be associated with high blood pressure or diabetes. The present study did not find such associations either.

Muscle mass seems to promote bone mass gain and maintenance because of the mechanical overload exerted by muscles on bones ${ }^{25}$. Genaro et al. ${ }^{26}$ found that sarcopenia is associated with lower femoral bone mineral density in menopausal women with osteoporosis. Di Monaco et al. ${ }^{27}$ found this same association in older Italian women who sustained a broken hip. Our result corroborates these studies since we also found an association between sarcopenia and osteopenia/osteoporosis in very old males and females. Additionally, these individuals are four times more likely to have sarcopenia.

One of the study limitations is the crosssectional design as it limits the ability of establishing causal relationships. However, we emphasize that studies about such aspects in adults aged 80 years or more are scarce.

\section{CONCLUSION}

The sociodemographic factors and chronic noncommunicable diseases independently associated with sarcopenia in adults aged 80 years and older are gender, age, nutritional status, and osteopenia/osteoporosis.

\section{ACKNOWLEDGMENTS}

We thank the Conselho Nacional de Desenvolvimento Científico e Tecnológico for the financial suport to Vanessa Ribeiro dos Santos.

\section{CONTRIBUTORS}

VR SANTOS selected the subjects; collected, analyzed and interpreted the data, and drafted, wrote, and reviewed the manuscript. DGD CHRISTOFARO analyzed and interpreted the data, and drafted the manuscript. IC GOMES selected the subjects; collected data, and drafted the manuscript. RR AGOSTINETE drafted the manuscript. LA GOBBO analyzed and interpreted the data, and drafted and reviewed the manuscript. IF FREITAS JÚNIOR selected the subjects; collected the data, and drafted and reviewed the manuscript.

\section{REFERENCES}

1. Doherty TJ. Invited review: Aging and sarcopenia. J Appl Physiol. 2003; 95(4):1717-27.

2. Baumgartner RN, Koehler KM, Gallagher D, Romero L, Heymsfield SB, Ross RR, et al. Epidemiology of sarcopenia among the elderly in New Mexico. Am J Epidemiol. 1998; 147(8):755-63.

3. Silva TAA, Frisoli Junior $A$, Pinheiro MM, Szejnfeld VL. Sarcopenia associada ao envelhecimento: aspectos etiológicos e opções terapêuticas. Rev Bras Reumatol. 2006; 46(6):391-7. http://dx.doi.org/ 10.1590/50482-50042006000600006

4. Penha JCL, Piçarro IC, Barros Neto TL. Evolution of physical fitness and functional capacity in active elderly women over 50 years of age according to chronological age in Santos city. Ciênc Saúde Colet. 2012; 17(1):245-53. http://dx.doi.org/10.1590/S14 $13-81232012000100027$ 
5. Pierine DT, Nicola M, Oliveira EP. Sarcopenia: alterações metabólicas e consequências no envelhecimento. R Bras Ci Mov. 2009; 17(3):96-103.

6. Cruz-Jentofth AJ, Baeyens JP, Bauer JM, Boirie Y, Cederholm T, Landi $F$, et al. Sarcopenia: European consensus on definition and diagnosis. Age Ageing. 2010; 39(4):412-23. http://dx.doi.org/10.1093/ ageing/afq034

7. Janssen I, Baumgartner RN, Ross R, Rosenberg I, Roubenoff R. Skeletal muscle cutpoints associated with elevated physical disability risk in older men and women. Am J Epidemiol. 2004; 159(4):413-21.

8. Genaro PS, Pereira GAP, Pinheiro MM, Szejnfeld VL, Martini LA. Influence of body composition on bone mass in postmenopausal osteoporotic women. Arch Gerontol Geriatr. 2010; 51(3):295-8. http://dx.doi. org/10.1016/j.archger.2009.12.006

9. Ward J. Sarcopenia and sarcopenic obesity: Is it time the health system accepted fitness of older people as a health responsibility? Australas J Ageing. 2011; 30(2):61-2. http://dx.doi.org/10.1111/j.1741-00 536.x

10. Lee JS, Auyeung TW, Kwok T, Lau EM, Leung PC, Woo J. Associated factors and health impact of sarcopenia in older Chinese men and women: A cross-sectional study. Gerontology. 2007; 53(6): 404-10.

11. Instituto Brasileiro de Geografia e Estatística. Censo demográfico e contagem da população: população residente por sexo, situação e grupos de idade. 2010 [acesso 2009 mar 30]. Disponível em <http// www.sidra.ibge.gov.br>.

12. Lebrão ML, Laurenti R. Saúde, bem-estar e envelhecimento. Rev Bras Epidemiol. 2005; 8(2):127-41. http://dx.doi.org/10.1590/S1415790X20050002 00005

13. Troiano RP, Frongillo EAJR, Sobal J, Levitsky DA. The relationship between body weight and mortality: A quantitative analysis of combined information from existing studies. Int J Obes Relat Metab Disord. 1996; 20(1):63-75.

14. World Health Organization. Prevention and management of osteoporosis: Report of a WHO scientific group. Geneva: WHO; 2003 [cited 2012 May 2]. Available from: http//whqlibdoc.who.int/ trs/who_trs_921.pdf

15. Gallagher D, Ruts E, Visser M, Heshka S, Baumgartner RN, Wang J, et al. Weight stability masks sarcopenia in elderly men and women. Am J Physiol Endocrinol Metab. 2000; 279(2):E366-75.

16. Roubenoff R, Hughes VA. Sarcopenia: Current concepts. J Gerontol A Biol Sci Med Sci. 2005; 55(12):M716-24.

17. Newman $A B$, Kupelian $V$, Visser $M$, Simonsick $E$, Goodpaster B, Nevitt M, et al. Sarcopenia: Alternative definitions and associations with lower extremity function. J Am Geriatr Soc. 2003; 51(11):1602-9.

18. Barbosa-Silva MC. Subjective and objective nutritional assessment methods: What do they really assess? Curr Opin Clin Nutr Metab Care. 2008; 11(3):248-54. http://dx.doi.org/10.1097/ MCO.0b013e3282fba5d7

19. Houston DK, Nicklas BJ, Ding J, Harris TB, Tylavsky $F A$, Newman $A B$, et al. Dietary protein intake is associated with lean mass change in older, community-dwelling adults: The Health, Aging, and Body Composition (Health $A B C$ ) study. Am J Clin Nutr. 2008; 87(1):150-5.

20. Aleman-Mateo H, Macias L, Esparza-Romero J, Astiazaran-Garcia H, Blancas AL. Physiological effects beyond the significant gain in muscle mass in sarcopenic elderly men: Evidence from a randomized clinical trial using a protein-rich food. Clin Interv Aging. 2012; 7:225-34. http://dx.doi. org/10.2147/CIA.S32356

21. Delmonico MJ, Harris TB, Lee JS, Visser M, Nevitt $M$, Kritchevsky SB, et al. Alternative definitions of sarcopenia, lower extremity performance, and functional impairment with aging in older men and women. J Am Geriatr Soc. 2007; 55(5):769-74.

22. Lau EMC, Lynn HSH, Woo JW, Kwok TC, Melton $\sqcup$, et al. Prevalence of and risk factors for sarcopenia in elderly Chinese men and women. J Gerontol A Biol Sci Med Sci. 2005; 60(2):213-6.

23. Gerace LA, Aliprantis M, Russell DB, Allison KM, Buhl JW, Wang ZM, et al. Skeletal differences between black and white men and their relevance to body composition estimates. Am J Human Biol. 1994; 6(2):255-62. http://dx.doi.org/10.1002/ajhb. 1310060215

24. Karakelides H, Nair KS. Sarcopenia of aging and its metabolic impact. Curr Top Dev Biol. 2005; 68:123-48.

25. Elefteriou F, Takeda S, Ebihara K, Magre J, Patano $N$, Kim CA, et al. Serum leptin level is a regulator of bone mass. Proc Natl Acad Sci. 2004; 101(9):3258-63.

26. Genaro OS, Pereira GAP, Pinheiro MM, Szejnfeld $\mathrm{VL}$, Martini LA. Influence of body composition on bone mass in postmenopausal osteoporotic women. Arch Gerontol Geriatr. 2010; 51(3):295-98. http://dx.doi.org/10.1016/j.archger.2009.12.006

27. Di Monaco M, Vallero F, DiMonaco R, Tappero R. Prevalence of sarcopenia and its association with osteoporosis in 313 older women following a hip fracture. Arch Gerontol Geriatr. 2011; 52(1):71-74. http://dx.doi.org/10.1016/j.archger.2010.02.002

Received: June 5, 2014 Final version: January 13, 2015 Approved: February 11, 2015 